\title{
SOIL PHYSICO-CHEMICAL PROPERTIES IN LAPALALA WILDERNESS OLD AGRICULTURAL FIELDS, LIMPOPO PROVINCE OF SOUTH AFRICA
}

\author{
RUWANZA, S. ${ }^{1,2^{*}}-$ MULAUDZI, D. ${ }^{1}$ \\ ${ }^{I}$ Department of Ecology and Resource Management, University of Venda \\ Private Bag X5050, Thohoyandou 0950, South Africa \\ ${ }^{2}$ Centre for Invasion Biology, Department of Ecology and Resource Management, University of \\ Venda, Thohoyandou 0950, South Africa \\ *Corresponding author \\ e-mail:ruwanza@yahoo.com; phone: +27-15-962-8573 \\ (Received 23 $3^{\text {rd }}$ Nov 2017; accepted $7^{\text {th }}$ Mar 2018)
}

\begin{abstract}
Natural recovery of abandoned agricultural fields take decades due to biotic and abiotic constraints. A key question is how does soil physico-chemical properties prevent the transition from degraded to restored state. This study examined changes in soil physico-chemical properties between old field sites that were abandoned 35 year ago and adjacent natural sites in Lapalala Wilderness, located in the Limpopo Province of South Africa. Top soils were collected from three paired sites (old field and natural sites) in five different locations, over three months and were quantified for soil moisture, total soil macro elements $(\mathrm{N}, \mathrm{C}$ and $\mathrm{P}), \mathrm{pH}$, exchangeable cations $(\mathrm{K}, \mathrm{Ca}, \mathrm{Mg}, \mathrm{Na})$, resistivity, penetration resistance, cumulative infiltration and hydraulic conductivity. Results show that soils in old field sites had lower $\mathrm{pH}$, total $\mathrm{N}$ and $\mathrm{C}, \mathrm{K}, \mathrm{Mg}$, gravimetric soil moisture and were compact compared to soils in adjacent natural sites. Soil resistivity, total $\mathrm{P}, \mathrm{Na}, \mathrm{Ca}$, cumulative infiltration and hydraulic conductivity showed no significant $(p>0.05)$ differences between the two sites. It appears that the soils in old field sites have poor properties, and indication that soil manipulation techniques e.g. fertilizer addition, top soil removal and soil transfer must be considered for vegetation recovery to take place.
\end{abstract}

Keywords: land abandonment, soil reconstruction, soil fertility, soil nutrient, litter

\section{Introduction}

Land abandonment commonly referred to as the termination of crop cultivation or livestock grazing is a widespread phenomenon in South Africa (Andrew et al., 2003). Social (rural depopulation, poor land use practices), economic (globalization of agricultural markets, shortage of capital) and ecological (declining soil fertility) reasons have been highlighted as causes for land abandonment (Andrew et al., 2003; Kakembo and Rowntree, 2003). The abandonment of land has a wide range of ecological consequences e.g. soil erosion, competitive exclusion, increased wildfires and invasion by invasive plants. All these consequences are linked to habitat loss and decline in ecosystem service provision (Plieninger et al., 2014). To restore abandoned agricultural lands (also referred to as old fields), models of ecological restoration (successional and alternative state) have been tried and they have produced mixed results (Hobbs and Suding, 2008). The broader objective of these models is to restore natural ecosystem processes, functions, and structure (Hobbs and Suding, 2008). For example, soil manipulation in old fields has aimed to improve soil properties with the view that improved soils will facilitate native vegetation recovery (Blumenthal et al., 2003; Ruwanza et al., 2012). Recent studies have shown that soil transfer from intact natural 
areas to old fields has the potential to recover both soils and plants in old fields (Wubs et al., 2016; Bulot et al., 2017).

The effect of land abandonment on soils has been varied. Some studies have shown that soils in old fields have high chemical properties compared to natural areas, this a result of past cultivation (Hooker and Compton, 2003; Gabarrón-Galeote et al., 2015). Additionally, some studies have shown that vegetation recolonization in old fields can influence soil changes (Bonet and Pausas, 2004), although the duration change is unclear. Since vegetation is known to be a driver of soil changes, variations in soil properties tend to be highly dependent on plant colonization (Gabarrón-Galeote et al., 2015). For example, secondary succession in Mediterranean environments usually starts with grasses and herbs, with a gradual increase in woody species over time (Rey Benayas, 2005; Cuesta et al., 2012). The above-mentioned changes in vegetation type contributes to changes in soil properties due to litter deposition and decomposition. Other studies have shown that the persistence of grassland cover combined with the slow recovery of woody species in semi-arid old fields result in the slow recovery of soil properties (Rey Benayas, 2005; Ruiz-Sinoga and Martínez-Murillo, 2009).

An understanding of changes in soil properties within old fields has the potential to improve our knowledge of ecological restoration in these areas. For instance, understanding the changes in soil properties in old fields has contributed to the development of new soil manipulation techniques (e.g. top soil removal and soil transfers) that are yielding successful plant and soil recovery (Wubs et al., 2016; Bulot et al., 2017). Besides that, insights into soil properties in old fields has helped our general understanding of bacterial and fungal activities, nutrient uptake and plant-soil interactions (McKinley et al., 2005). Therefore, the objective of this study was to assess the differences in soil physico-chemical properties between old field sites and adjacent natural sites in Lapalala Wilderness, South Africa. The research question was whether soil properties, namely soil physico-chemical properties, resistivity, penetration resistance, infiltration and hydraulic conductivity are different between old field sites and adjacent natural sites. Results of this study are envisaged to guide future restoration initiatives in Lapalala Wilderness old fields.

\section{Materials and methods}

\section{Study sites and soil collection}

Soils were collected at three different sites that were located at Lapalala Wilderness in the Limpopo province of South Africa (Table 1 and Fig. 1A). The three sites were approximately $200 \mathrm{~m}$ apart to provide a measure of independence (Galatowitsch and Richardson, 2005), and each old field site was paired with a natural site, approximately $10 \mathrm{~m}$ from each other (road demarcation). The mean annual rainfall in this area is approximately $500 \mathrm{~mm}$, which falls in the summer months between October and February. Temperatures in the area are cold in winter and hot in summer with mean daily maximum and minimum temperatures of $30{ }^{\circ} \mathrm{C}$ in January and $14{ }^{\circ} \mathrm{C}$ in June. Vegetation in the area is classified as Waterberg Mountain Bushveld, which is found in the savanna biome (Mucina and Rutherford, 2006). Soils in the area are nutrient poor sandy soils derived from the Kransberg subgroup of the Waterberg groups (Mucina and Rutherford, 2006). However, the central sections of Lapalala Wilderness are dominated by nutrient rich clay soils derived from norite/epidiorite intrusions. The dominant plant species in the natural areas include Dichrostachys cinerea, Sclerocarya birrea, 
Vachellia tortilis, Ziziphus mucronata, Grewia spp, Arisitida congesta, Panicum maximum, Eragrostis rigidior and Aristida adscensionis. The old field sites were previously used for tobacco and cattle farming approximately 35 years ago. Currently, they are used for animal grazing and are dominated by few scattered woody pioneer species ( $V$. karroo) and low grass cover.

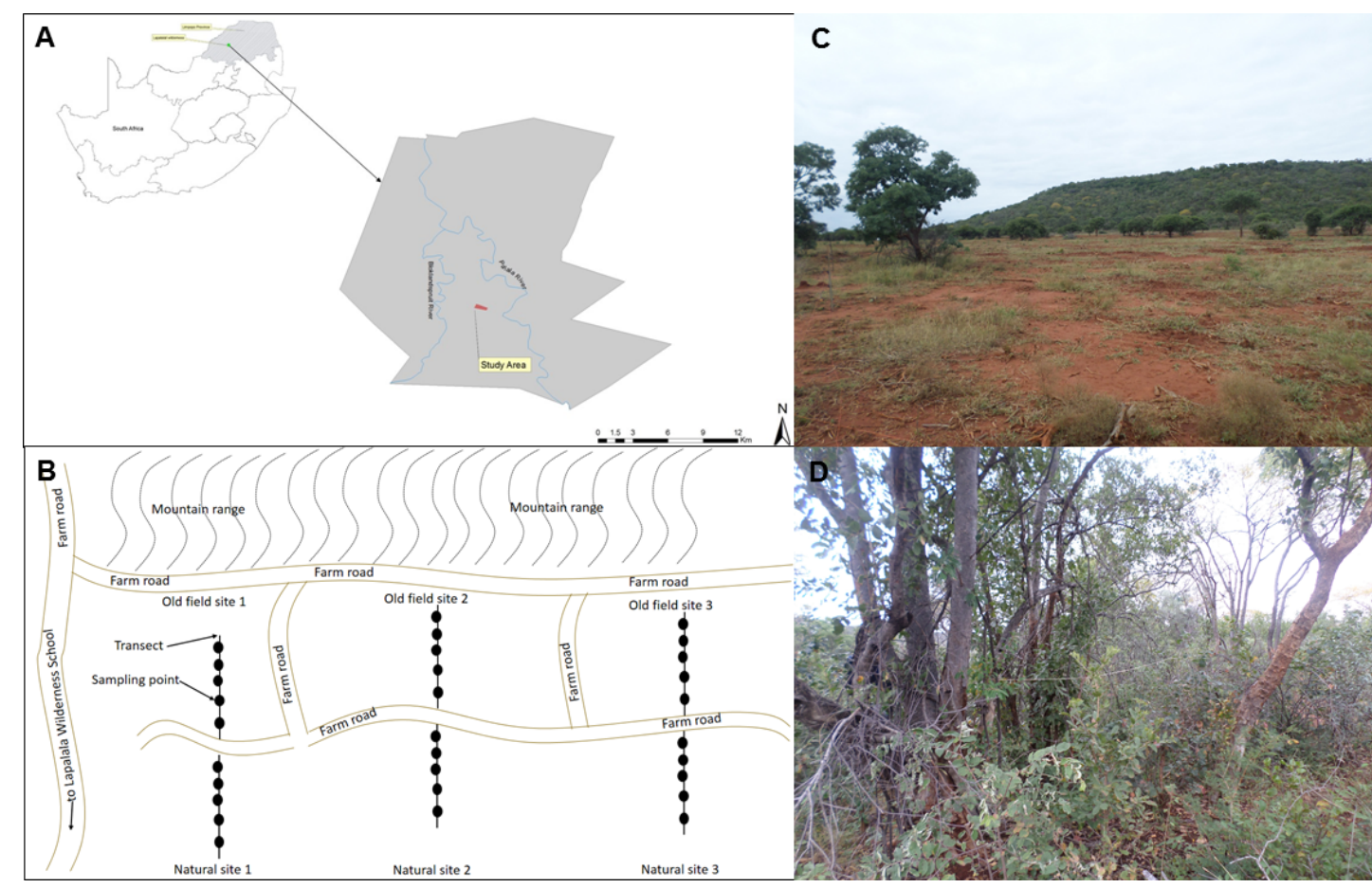

Figure 1. Map showing (A) the location of the Lapalala Wilderness study area in the Limpopo Province, South Africa and (B) the experimental setup in the old fields, (C) photo of old field, and (D) photo of natural site. Location details of the sites are presented in Table 1. Photos taken by Sheunesu Ruwanza

At each site, a $40 \mathrm{~m}$ transect (from west to east) running into the site, with the first point being $2 \mathrm{~m}$ from the road demarcating paired sites, was established. The abovementioned transect comprised five soil collecting points that were $10 \mathrm{~m}$ apart (Fig 1B). Therefore, a total of 30 soil collecting points were marked, thus five soil samples points per site from six sites (three old field sites and three natural sites). In April 2017, two soil cores $(30 \mathrm{~cm}$ apart) were collected at each collecting point for soil physicochemical and moisture analysis. The soil physico-chemical analysis was done once due to limited finance. Besides, the expectation that repeated monthly measurements on soil physico-chemical properties would yield variations within three months was less. During the months of May and June, 30 soil cores per month were collected for soil moisture measurements only. Therefore, a total of 60 soil sample were collected in April (30 for physico-chemical analysis and 30 soil moisture measurements) and 30 soil cores per month for the months of May and June for soil moisture measurements. The soils were collected using a soil core measuring $8 \mathrm{~cm}$ in diameter and $8 \mathrm{~cm}$ depth after the hand removal of overlying debris. After soil collection, both soil physico-chemical properties and soil moisture measurements were assessed under laboratory conditions at the University of Venda in Thohoyandou, South Africa. Measurements on soil 
penetration resistance level and infiltration rate were conducted under field conditions at each of the soil collecting points for all the three months.

Table 1. Characteristics of the three paired study sites located in Lapalala Wilderness in the Limpopo Province of South Africa. Old filed sites and natural sites were adjacent to each other

\begin{tabular}{c|c|c|c|c}
\hline Site number & Site identification & Site status & Coordinates & Soil texture $^{\text {* }}$ \\
\hline \multirow{2}{*}{ Site 1} & Site $1 \mathrm{a}$ & Old field site & $23^{\circ} 51^{\prime} 53.83^{\prime \prime} \mathrm{S}, 28^{\circ} 18^{\prime} 09.55^{\prime \prime} \mathrm{E}$ & Loam \\
\cline { 2 - 5 } & Site $1 \mathrm{~b}$ & Adjacent natural site & $23^{\circ} 51^{\prime} 48.91$ "S, $28^{\circ} 18^{\prime} 12.36$ "E & Loam and clay \\
\hline \multirow{2}{*}{ Site 2} & Site $2 \mathrm{a}$ & Old field site & $23^{\circ} 51^{\prime} 52.15^{\prime \prime} \mathrm{S}, 28^{\circ} 17^{\prime} 51.58^{\prime \prime} \mathrm{E}$ & Clay \\
\cline { 2 - 5 } & Site $2 \mathrm{~b}$ & Adjacent natural site & $23^{\circ} 51^{\prime} 42.56^{\prime \prime} \mathrm{S}, 28^{\circ} 17^{\prime} 53.53^{\prime \prime} \mathrm{E}$ & Clay \\
\hline \multirow{2}{*}{ Site 3 } & Site 3a & Old field site & $23^{\circ} 51^{\prime} 48.12^{\prime \prime} \mathrm{S}, 28^{\circ} 17^{\prime} 35.04 " \mathrm{E}$ & Loam and clay \\
\cline { 2 - 5 } & Site $3 \mathrm{~b}$ & Adjacent natural site & $23^{\circ} 51^{\prime} 37.83^{\prime \prime} \mathrm{S}, 28^{\circ} 17^{\prime} 41.09^{\prime \prime} \mathrm{E}$ & Loam and clay \\
\hline
\end{tabular}

${ }^{*}$ Textural classes according to handbook of standard soil testing methods (1990) for advisory purposes.

Compiled by the non-affiliated soil analysis work committee, Soil Science Society of South Africa

\section{Soil chemical properties and $\mathrm{pH}$}

Soil $\mathrm{pH}$ was measured in 1:5 soil: $\mathrm{KCl}$ extract (Rhoades, 1982). Soil total $\mathrm{P}$ was analyzed using Bray-II extract method (Bray and Krutz, 1945). Soil total N was analyzed using the complete combustion method using an elemental analyzer (Euro EA; Eurovector, Milan, Italy). Soil total $\mathrm{C}$ was analyzed using the modified Walkley-Black method (Chan et al., 2001). Exchangeable cations were extracted in a 1:10 ammonium acetate solution using the centrifuge procedure (Thomas, 1982), filtered and analyzed by atomic absorption spectrometry (SP428; LECO Corporation, St. Joseph, Michigan, USA).

\section{Soil physical properties}

Soil resistivity, gravimetric soil moisture, and soil penetration resistance levels

Soil resistivity was measured using a resistivity meter. Gravimetric soil moisture, which calculates soil moisture using the difference between the fresh and dry weight, was calculated by first weighing wet soils, drying them in an oven at $105^{\circ} \mathrm{C}$ for $72 \mathrm{~h}$, then reweighing to obtain the water content (Black, 1965). Gravimetric soil measurements were expressed as a percentage. Soil penetration resistance levels were measured using a pocket penetrometer (SOILTEST, Inc., Evanston, Illinois, USA). When the penetrometer is pushed into the soil, it pushes a metal ring to scale, marking the penetration resistance value in $\mathrm{kg} \mathrm{cm}^{-2}$ (Leung and Meyer, 2003).

\section{Soil infiltration and hydraulic conductivity}

Soil infiltration rate and hydraulic conductivity were measured using a mini disk infiltrometer (Decagon Devices, Pullman, WA, USA). The infiltrometer, an acrylic tube with a semipermeable plastic disk and a rubber stopper, consists of two chambers which were all filled with water. The upper chamber controls suction, whilst the lower chamber allows infiltration and a small tube inside the disk regulates the suction rate, which was set at $2.0 \mathrm{~cm}$ in this experiment (Latorre et al., 2013). Measurements were 
taken on the soil surface after hand removal of litter. The water infiltration rate was measured at every $30 \mathrm{~s}$ intervals for $5 \mathrm{~min}$ from the drop-in water level of the lower chamber in $\mathrm{mL}$. The infiltration rate was determined from the measured cumulative infiltration rate over time using the method of Zhang (1997). The level of soil hydraulic conductivity was calculated from the infiltration data using the van Genuchten-Zhang method (Zhang, 1997, 1998). For more information regards the method of calculating hydraulic conductivity and the equation used see mini disk infiltrometer manual at Decagon Devices (2014).

\section{Statistical analysis}

Data were analyzed using STATISTICA version 13 (StatSoft, 2015). Proof of normality and homogeneity of variance were assessed on all measurements using Kolmogorov-Smirnov tests and Levene's test respectively and data were normally distributed. Comparisons on soil $\mathrm{Ph}$, resistivity, total nutrient concentrations $(\mathrm{P}, \mathrm{N}$ and $\mathrm{C})$ and exchangeable cations $(\mathrm{K}, \mathrm{Na}, \mathrm{Ca}$ and $\mathrm{Mg}$ ) between old field sites and natural sites were analyzed using a $t$-test since data were collected once in April. Gravimetric soil moisture content, soil penetration resistance levels, and soil hydraulic conductivity were analyzed using a repeated measures ANOVA since data were collected over 3 months on the same transect. Where ANOVAs were significant, the Tukey's honestly significant difference Unequal $n$ test was used to determine the differences between site conditions and months at $p<0.05, p<0.01$ and $p<0.001$.

\section{Results}

\section{Soil chemical properties and $\mathrm{pH}$}

Soils in both old field sites and natural sites were clay (57\%) and loam (43\%). The soils in old field sites were very acidic with an average $\mathrm{pH}$ of $4.73 \pm 0.15$ and those in natural soils were strongly acidic with an average $\mathrm{pH}$ of $5.13 \pm 0.20$, with no significant $(p>0.05)$ difference between the two sites (Table 2). Similarly, soil $\mathrm{P}$ showed no significant $(p>0.05)$ difference between old field sites and natural sites (Table 2). Both soil total $\mathrm{N}$ and $\mathrm{C}$ were significantly $(p<0.001)$ higher in natural sites than in old field sites. The exchangeable cations of $\mathrm{K}$ and $\mathrm{Mg}$ were significantly $(p<0.01)$ higher in natural sites than in old field sites (Table 2). In contrast, the exchangeable cations of $\mathrm{Na}$ and $\mathrm{Ca}$ showed no significant $(p>0.05)$ difference between old field sites and natural sites (Table 2).

\section{Soil physical properties}

\section{Soil resistivity, gravimetric soil moisture, and soil penetration resistance levels}

Soil resistivity showed no significant $(p>0.05)$ difference between old field sites and natural sites (Table 2 ). The gravimetric soil moisture content varied significantly between the two sites $(p<0.001)$ and the three months $(p<0.001)$. Gravimetric soil moisture content was significantly $(p<0.001)$ higher in natural sites $(8.13 \pm 0.63)$ compared to old field sites $(5.94 \pm 0.31)$. The observed above-mentioned significant $(p<0.001)$ differences were recorded in April and June, but not in May (Fig. 2A). There was significant interaction $(p<0.01)$ between the site conditions and the months for gravimetric soil moisture content (Fig. 2A). Soil penetration resistance levels also 
varied significantly between the two sites $(p<0.001)$ and the three months $(p<0.001)$. Significantly $(p<0.001)$ higher soil penetration resistance levels were recorded in old field sites $(3.87 \pm 0.07)$ than in natural sites $(1.43 \pm 0.08)$. These above-mentioned significant $(p<0.001)$ differences were observed in all the three months (Fig. 2B). Interactions between site conditions and months in relation to soil penetration resistance levels showed significant $(p<0.001)$ difference (Fig. $2 B)$.

Table 2. Soil physico-chemical properties of soil samples taken from old field sites and adjacent natural sites. Data are means \pm se and t-test results are shown $\left({ }^{*} p<0.05\right.$, $\stackrel{* *}{p}<0.01, \stackrel{* * *}{p}<0.001) . N S=$ not significant and $p>0.05$

\begin{tabular}{|c|c|c|c|}
\hline Soil properties & Old field sites $(n=15)$ & Natural sites $(n=15)$ & T test values \\
\hline $\mathrm{pH}$ & $4.73 \pm 0.15$ & $5.13 \pm 0.20$ & $2.35^{*}$ \\
\hline Soil Resistivity $(\mathrm{Ohm})$ & $1733.33 \pm 272.02$ & $1284.67 \pm 188.15$ & $1.36 \mathrm{~ns}$ \\
\hline \multicolumn{4}{|c|}{ Total nutrient concentrations $(\mathrm{mg} / \mathrm{kg})$} \\
\hline P Bray II & $2.84 \pm 0.34$ & $3.17 \pm 0.33$ & $0.70 \mathrm{~ns}$ \\
\hline Total $\mathrm{N}$ & $373.33 \pm 78.96$ & $2166.67 \pm 304.36$ & $5.70^{* * * *}$ \\
\hline Total C & $8113.33 \pm 652.82$ & $19540.00 \pm 1308.54$ & $7.81^{* * *}$ \\
\hline \multicolumn{4}{|c|}{ Exchangeable cations (mg/kg) } \\
\hline $\mathrm{K}$ & $108.96 \pm 17.47$ & $217.66 \pm 29.33$ & $3.18 * *$ \\
\hline $\mathrm{Na}$ & $17.79 \pm 0.85$ & $19.17 \pm 1.57$ & $0.77 \mathrm{~ns}$ \\
\hline $\mathrm{Ca}$ & $924.00 \pm 160.96$ & $1380.40 \pm 202.43$ & $1.76 \mathrm{~ns}$ \\
\hline $\mathrm{Mg}$ & $248.56 \pm 37.47$ & $411.68 \pm 39.82$ & $2.98 * *$ \\
\hline
\end{tabular}
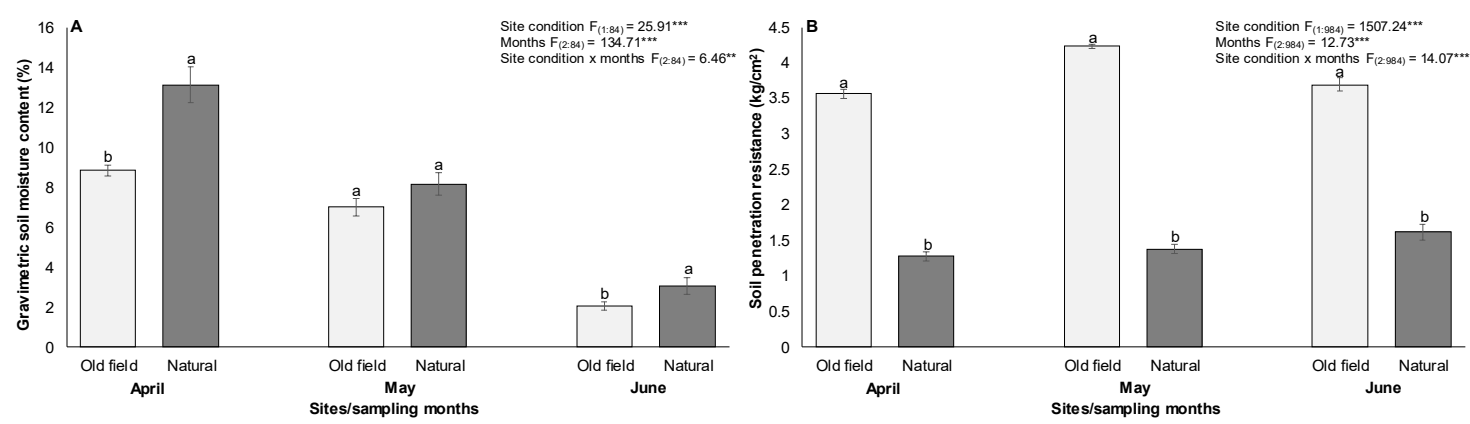

Figure 2. Results show (A) gravimetric soil moisture content (\%) and (B) soil penetration resistance levels $\left(\mathrm{kg} / \mathrm{cm}^{2}\right)$ in soil samples taken from old field sites and adjacent natural sites. Bars represent mean \pm se and results of repeated measures ANOVAs are shown $\left({ }^{*} p<0.05,{ }^{* *} p\right.$ $\left.<0.01,{ }^{* * *} p<0.001\right)$. Bars with different superscripts are significantly different at $p<0.05$. NS $=$ not significant and $p>0.05$

\section{Soil infiltration and hydraulic conductivity}

Cumulative infiltration rates showed no significant $(p>0.05)$ difference between old field sites and natural sites (Fig. 3A, B, C). The average cumulative infiltration rates for all the three months in the old field sites was $23.78 \pm 1.5 \mathrm{~cm}$, compared to $17.31 \pm 1.1$ $\mathrm{cm}$ in the natural sites after $5 \mathrm{~min}$, and these showed no significant $(p>0.05)$ difference between the three months (Fig. 3A, B,C). Contrary, interactions between site conditions and months in relation to cumulative infiltration rates showed significant $(p<0.01)$ 
difference (Fig. 3A, B, C). Soil hydraulic conductivity levels varied significantly between the two sites $(p<0.05)$, but not between the three months $(p>0.05)$. The observed above-mentioned significant $(p<0.05)$ differences between sites showed higher soil hydraulic conductivity levels in natural sites $(12.99 \pm 2.67)$ than in old field sites $(8.75 \pm 2.04)$ (Fig. 4). Monthly differences in soil hydraulic conductivity levels were only observed in June. Interactions between site conditions and the three months in relation to soil hydraulic conductivity levels showed no significant $(p>0.05)$ difference (Fig. 4).
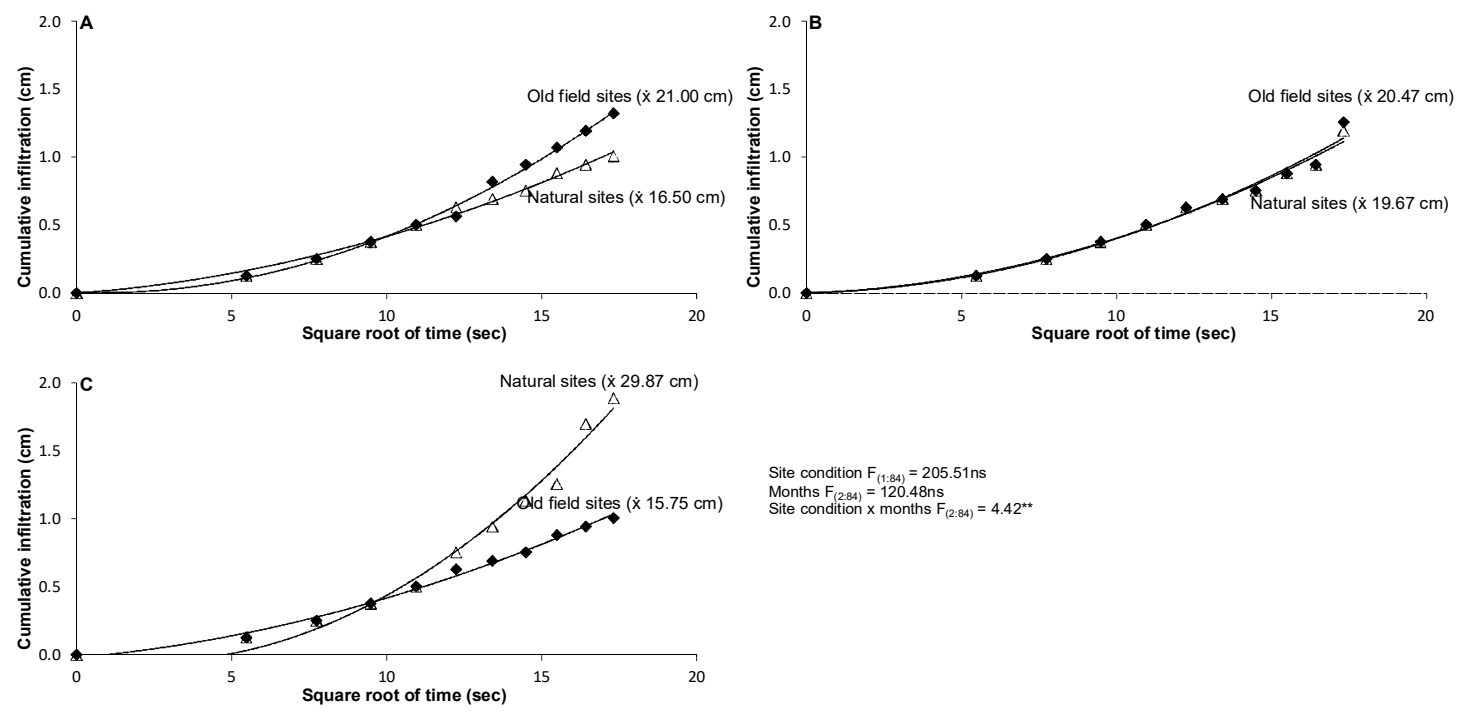

Figure 3. Cumulative infiltration levels in soil samples taken from old field sites and adjacent natural sites for the months (A) April, (B) May, and (C) June. Results of repeated measures ANOVAs (based on average infiltration rate after five minutes) are shown ( ${ }^{*} p<0.05$, $\left.{ }^{* *} p<0.01,{ }^{* * *} p<0.001\right) . N S=$ not significant and $p>0.05$

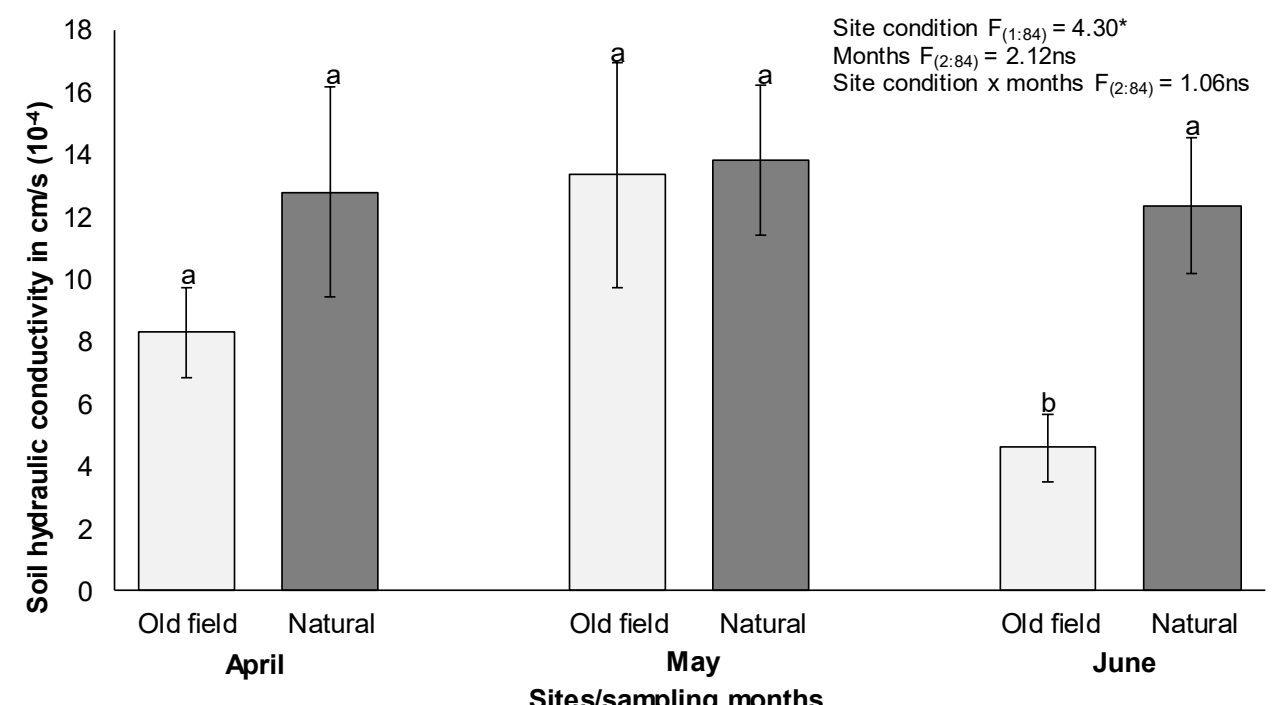

Figure 4. Soil hydraulic conductivity levels in soil samples taken from old field sites and adjacent natural sites. Bars represent mean \pm se and results of repeated measures ANOVAs are shown. Bars with similar letter superscripts are not significantly different at $p>0.05 . N S=n o t$ significant and $p>0.05$ 


\section{Discussion}

Results of this study showed that soil properties differ between old field sites and adjacent natural sites. Soils under natural sites had higher $\mathrm{pH}$, total $\mathrm{N}$, total $\mathrm{C}, \mathrm{K}, \mathrm{Mg}$, gravimetric soil moisture and were less compact compared to soils in old field sites. Contrary, soil resistivity levels, total $\mathrm{P}, \mathrm{Na}, \mathrm{Ca}$, cumulative infiltration and soil hydraulic conductivity (except in June) showed no significant differences between the two sites. These results (for some soil chemical properties) concur with previous studies that have shown reduced soil properties in old fields with such reductions linked to years since abandonment (Odum et al., 1984; Feng et al., 2007; Cuesta et al., 2012). Odum et al. (1984) showed that soil $\mathrm{P}$ and $\mathrm{Ca}$ declined in top soils 10 years after land abandonment. Feng et al. (2007) showed mixed results, a decrease in available P and an increase in total and available $\mathrm{N}, \mathrm{K}$ and total $\mathrm{P}$ with increase in field abandonment age. Cuesta et al. (2012) reported higher soil $\mathrm{C}, \mathrm{NH}_{4} \mathrm{~N}$, and available $\mathrm{N}$ in reforested areas than in old fields, however, they also showed no changes in soil $\mathrm{pH}$, total $\mathrm{N}, \mathrm{P}, \mathrm{K}$, $\mathrm{NO}_{3} \mathrm{~N}$ and $\mathrm{P}$ between the two sites. These above-mentioned studies point to current environmental conditions (e.g. type of plant species present in both old fields and natural sites) as the driver to changes in soil properties (Odum et al., 1984; Feng et al., 2007; Cuesta et al., 2012). For example, different plant communities differ in their capacity to modify soil properties, given that plant functional traits such as growth form, biomass allocation, and tissue chemistry can affect organic matter decomposition and nutrient dynamics (Carrera et al., 2009).

Changes in soil properties in our old fields could be a result of several factors that include past fertilization, vegetation recovery stage and the type of plant species present in the old fields (Feng et al., 2007; Cramer et al., 2008; Cuesta et al., 2012). Theories on soil recovery following land abandonment posit that soil nutrients especially $\mathrm{N}, \mathrm{C}$ and $\mathrm{P}$ will be high soon after land abandonment because of previous agricultural practices (McLauchlan, 2006: Cramer et al., 2008). As the recovery process progresses and plant communities begin to occupy old fields, some soil nutrients tend to decrease due to utilization by plants (Feng et al., 2007). However, as vegetation cover and organic matter content increase, soil nutrients are likely to increase with time, although this is dependent on the type of colonizing plants. Contrary, soil nutrient losses during early vegetation recovery stages are exacerbated by soil erosion and nutrient leaching which are known to be high in less vegetated old fields (Shen and Hong, 2003).

Based on above-mentioned vegetation recovery theories in old field, we anticipated that soil properties in our 35-year old fields should be similar to those in natural sites. Contrary, we found the opposite for some soil properties. We suggest that the lack of vegetation, which is linked to increased soil erosion, could explain the observed reduced soil nutrient in old field sites. Only a few scattered pioneer trees (e.g. Vachellia karoo and Senegalia nigrescens) and grass (e.g. Cynodon dactylon and Panicum maximum) species were observed in old fields (Sheunesu Ruwanza, personal observation; see photo on Fig. 1C). Previous studies have shown that the absence of vegetation in old fields is associated with low soil nutrient levels (McLauchlan, 2006: Cramer et al., 2008), this linked to reduced litter content, organic matter, and decomposition rate. Plant litter accumulation is known to improve soil nutrients especially soil N, C, and P, this because of decomposing residual (McLauchlan, 2006; Austin and Ballaré, 2010; Bansal et al., 2014). There is considerable evidence that litter plays an important role in soil carbon storage and nutrient cycle which in turn affect soil nutrients (Aerts and de Caluwe, 1997; Marínez-Yrzar et al., 2007), this likely to be the case in reported high 
soil nutrient content in natural sites which are vegetated. It is well reported that soil $\mathrm{pH}$ influences solubility of soil nutrients, making them available in insufficient quantities in acidic soils (Kidd and Proctor, 2001), as are the soils in Lapalala Wilderness old field sites. Besides soil pH being a factor affecting soil nutrient availability, the reported soil compaction and low soil moisture levels in old field sites can explain soil nutrient reductions. Moist and less compact soils are known to promote decomposition and release of soil nutrients as compared to dry and compact soils (Wolf et al., 2013; Van Horn et al., 2014), as are the soils at Lapalala Wilderness old field sites.

Low vegetation cover in old field sites, which created barren soil surfaces, has been reported to promote soil erosion and nutrient leaching (Lesschen et al., 2008). Loss of soils due to erosion is directly linked to a decrease in soil nutrients (Xue et al., 2011). Also, lack of vegetation which is linked to low above-ground biomass and litter can reduce $\mathrm{C}$ input into soils, which then influences soil micro-aggregate formation leading to accelerated soil erosion (Wan and Luo, 2003). This likely to take place in less vegetated old field sites than in vegetated natural sites. The reported compact soils in the old field sites could also facilitate erosion and nutrient leaching due to low infiltration capacity which promotes runoff. Indeed, previous studies have reported that soil compaction reduces soil porosity (Silva et al., 2008) thus causing low soil water infiltration (Nawaz et al., 2013) which subsequently increase soil erosion.

\section{Conclusions}

This study provides evidence of the poor state of soils in Lapalala Wilderness old fields, several years after land abandonment. The persistence of these soils in a poor state may hamper both soil and vegetation recovery. Therefore, active soil manipulations techniques should be considered if soils in Lapalala Wilderness old fields are to be improved. Different techniques to improve soil properties in old fields can be used e.g. soil nutrient manipulation (fertilizers or organic matter addition), top soil removal and soil transfer (Blumenthal et al., 2003; Ruwanza et al., 2012). The abovementioned approaches have been shown to improve soil properties in old fields (Holmes, 2008; Blumenthal et al., 2003; Wubs et al., 2016; Bulot et al., 2017). Not only do they improve soil properties, they also steer plant community recovery (Wubs et al., 2016). However, the feasibility of these above-mentioned techniques in Lapalala Wilderness old fields needs to be tested.

Acknowledgements. This research study was funded by the University of Venda under the research and development directorate. We are grateful to the owners, the managing director (Mr. Anton Walker), the conservation manager (Mr. Hermann Muller) and the research coordinator (Dr. Annemieke van der Goot) at Lapalala Wilderness for permission to conduct my research work and for logistical help during our field work.

\section{REFERENCES}

[1] Aerts, A., de Caluwe, H. (1997): Nutritional and plant-mediated controls on leaf litter decomposition of Carex species. - Ecology 78(1): 244-260.

[2] Andrew, M., Ainslie, A., Shackleton, C. (2003): Land use and livelihoods. - Programme for Land and Agrarian Studies, School of Government, University of the Western Cape, 
South Africa (Evaluating Land and Agrarian Reform in South Africa occasional paper series, No. 8).

[3] Austin, A. T., Ballaré, C. L. (2010): Dual role of lignin in plant litter decomposition in terrestrial ecosystems. - Proceedings of the National Academy of Sciences of the United States of America 107(10): 4618-4622.

[4] Bansal, S., Sheley, R. L., Blank, B., Vasquez, E. A. (2014): Plant litter effects on soil nutrient availability and vegetation dynamics: changes that occur when annual grasses invade shrub-steppe communities. - Plant Ecology 215: 367-378.

[5] Black, C. A. (1965): Methods of Soil Analysis: Part I Physical and Mineralogical Properties. - American Society of Agronomy, Madison, WI, USA.

[6] Blumenthal, D. M., Jordan, N. R., Russelle, M. P. (2003): Soil carbon addition controls weeds and facilitates prairie restoration. - Ecological Applications 13: 605-615.

[7] Bonet, A., Pausas, J. G. (2004): Species richness and cover along a 60-year chronosequence in old-fields of southeastern Spain. - Plant Ecology 174: 257-270.

[8] Bray, R. H., Krutz, L. T. (1945): Determination of total, organic and available forms of phosphorus in soils. - Soil Science 59: 39-45.

[9] Bulot, A., Potard, K., Bureau, F., Berard, A., Dutoit. T. (2017): Ecological restoration by soil transfer: impacts on restored soil profiles and topsoil functions. - Restoration Ecology 25: 354-366.

[10] Carrera, A. L., Mazzarino, M. J., Bertiller, M. B., del Valle, H. F., Carretero, E. M. (2009): Plant impacts on nitrogen and carbon cycling in the Monte Phytogeographical Province, Argentina. - Journal of Arid Environments 73: 192-201.

[11] Chan, K. Y., Bowman, A., Oates, A. (2001): Oxidizible organic carbon fractions and soil quality changes in an Oxic Paleustalf under different pasture leys. - Soil Science Society of America Journal 166: 61-67.

[12] Cramer, V. A., Hobbs, R. J., Standish, R. J. (2008): What's new about old fields? Land abandonment and ecosystem assembly. - Trends in Ecology and Evolution 23: 104-112.

[13] Cuesta, B., Rey Benayas, J. M., Villar-Salvador, P., González-Espinosa, M. (2012): Soil chemical properties in abandoned Mediterranean cropland after succession and oak reforestation. - Acta Oecologica 38: 58-65.

[14] Decagon. (2014): Minidisk Infiltrometer User's Manual. - Decagon Devices, Inc., Pullman, USA.

[15] Feng, D., Hong-Bo, S., Lun, S., Zong-Suo, L., Ming-Ana, S. (2007): Secondary succession and its effects on soil moisture and nutrition in abandoned old-fields of hilly region of Loess Plateau, China. - Colloids and Surfaces B: Biointerfaces 58: 278-285.

[16] Gabarrón-Galeote, M. A., Trigalet, S., van Wesemael, B. (2015): Effect of land abandonment on soil organic carbon fractions along a Mediterranean precipitation gradient. - Geoderma 249-250: 69-78.

[17] Galatowitsch, S, Richardson, D. M. (2005): Riparian scrub recovery after clearing of invasive alien trees in headwater streams of the Western Cape, South Africa. - Biological Conservation 122: 509-521.

[18] Hobbs, R. J., Suding, K. N. (2008): New Models for Ecosystem Dynamics and Restoration. - Island Press, Washington, DC.

[19] Holmes, P. M. (2008): Optimal ground preparation treatments for restoring lowland Sand Fynbos vegetation on old fields. - South African Journal of Botany 74: 33-40.

[20] Hooker, T. D., Compton, J. E. (2003): Forest ecosystem carbon and nitrogen accumulation during the first century after agricultural abandonment. - Ecological Applications 13: 299-313.

[21] Kidd, P. S., Proctor, J. (2001): Why plants grow poorly on very acidic soils: are ecologists missing the obvious? - Journal of Experimental Botany 52: 791-799.

[22] Kakembo, V., Rowntree, K. M. (2003): The relationship between land use and soil erosion in the communal lands near Peddie Town, Eastern Cape, South Africa. - Land Degradation and Development 14:39-49. 
[23] Latorre, B., Moret-Fernández, D., Peña, C. (2013): Estimate of soil hydraulic properties from disc infiltrometer three-dimensional infiltration curve: theoretical analysis and field applicability. - Procedia Environmental Science 19: 580-589.

[24] Lesschen, J. P., Cammeraat, L. H., Nieman, T. (2008): Erosion and terrace failure due to agricultural land abandonment in a semi-arid environment. - Earth Surface Processes and Landforms 33(10): 1574-1584.

[25] Leung, Y-F., Meyer, K. (2003): Soil Compaction as Indicated by Penetration Resistance: A Comparison of Two Types of Penetrometers. - In: Harmon, D., Kilgore, B. M., Vietzke, G. E. (eds.) Protecting Our Diverse Heritage: The role of Parks, Protected Areas, and Cultural Sites. Proceedings of the George Wright Society/National Park Service Joint Conference, pp. 370-375. GWS, Hancock, MI.

[26] Marínez-Yrzar, A., Núñez, S., Búrquez, A. (2007): Leaf litter decomposition in a southern Sonoran desert ecosystem, northwestern Mexico: effects of habitat and litter quality. - Acta Oecologica 32(3): 291-300.

[27] McKinley, V. L., Peacock, A. D., White, D. C. (2005): Microbial community PLFA and PHB responses to ecosystem restoration in tallgrass prairie soils. - Soil Biology and Biochemistry 37: 1946-1958.

[28] McLauchlan, K. (2006): The nature and longevity of agricultural impacts on soil carbon and nutrients: a review. - Ecosystems 9: 1364-1382.

[29] Mucina, L., Rutherford, M. C. (2006): The Vegetation of South Africa, Lesotho and Swaziland. - Strelitzia 19, South African National Biodiversity Institute, Pretoria.

[30] Nawaz, M. F., Bourrié, G., Trolard, F. (2013): Soil compaction impact and modelling. A review. - Agronomy for Sustainable Development 33: 291-309.

[31] Odum, E. P., Pinder III, J. E., Christiansen, T. A. (1984): Nutrient losses from sandy soils during old-field succession. - The American Midland Naturalist 111(1): 148-154.

[32] Plieninger, T., Hui, C., Gaertner, M., Huntsinger, L. (2014): The impact of land abandonment on species richness and abundance in the Mediterranean Basin: A metaanalysis. - PLoS ONE 9(5): e98355. DOI: 10.1371/journal.pone.0098355.

[33] Rey Benayas, J. M. (2005): Restoration after Land Abandonment. - In: Mansourian, S., Vallauri, D., Dudley, N. (eds.) Forests Restoration in Landscapes: Beyond Planting Trees, pp. 356-360. Springer, New York, USA.

[34] Rhoades, J. D. (1982): Cation Exchanger Capacity. - In: Page, A. L., Miller, A. L, Keeney, R. H. (eds.) Methods of Soil Analysis, $2^{\text {nd }}$ ed., pp. 147-157. American Society of Agronomy, Madison, WI.

[35] Ruiz-Sinoga, J. D., Martínez-Murillo, J. F. (2009): Eco-geomorphological system response variability to the 2004-06 drought along a climatic gradient of the Littoral Betic Range (southern Spain). - Geomorphology 103: 351-362.

[36] Ruwanza, S., Musil, C. F., Esler, K. J. (2012): Sucrose application is ineffectual as a restoration aid in a transformed southern African lowland fynbos ecosystem. - South African Journal of Botany 80: 1-8.

[37] Shen, Y. C., Hong, Q. H. (2003): Strategy to control soil erosion effectively in the Loess Plateau. - Soil and Water Conservation 1(2): 22-27.

[38] Silva, S., Barros, N., Costa, L., Leite, F. (2008): Soil compaction and eucalyptus growth in response to forwarder traffic intensity and load. - Revista Brasileira de Ciência do Solo 32: 921-932.

[39] StatSoft, Inc. (2015): STATISTICA (Data Analysis Software System), Version 16. http://www. statsoft.com.

[40] Thomas, G. W. (1982): Exchangeable Cations. - In: Page, A. L., Miller, A. L., Keeney, R. H. (eds.) Methods of Soil Analysis, $2^{\text {nd }}$ ed., pp. 159-162. American Society of Agronomy, Madison, WI.

[41] Van Horn, D. J., Okie, J. G., Buelow, H. N., Gooseff, M. N., Barrett, J. E., TakacsVesbach, C. D. (2014): Soil microbial responses to increased moisture and organic 
resources along a salinity gradient in a polar desert. - Applied Environmental Microbiology 80: 3034-3043.

[42] Wan, S. Q., Luo, Y. Q. (2003): Substrate regulation of soil respiration in a tallgrass prairie: results of a clipping and shading experiment. - Global Biogeochemical Cycles 17: 1054-1065.

[43] Wolf, A. B., Vos, M., de Boer, W., Kowalchuk, G. A. (2013): Impact of matric potential and pore size distribution on growth dynamics of filamentous and non-filamentous soil bacteria. - PLoS One 8: e83661.

[44] Wubs, E. R. J, van der Putten, W. H., Bosch, M., Bezemer, T. M. (2016): Soil inoculation steers restoration of terrestrial ecosystems. - Nature Plants 2: 16107. DOI: 10.1038/nplants.2016.107.

[45] Xue, X., Luo, Y., Zhou, X., Sherry, R., Jia, X. (2011): Climate warming increases soil erosion, carbon and nitrogen loss with biofuel feedstock harvest in tallgrass prairie. Global Change Biology Bioenergy 3: 198-207.

[46] Zhang, R. (1997): Determination of soil sorptivity and hydraulic conductivity from the disk infiltrometer. - Soil Science Society of America Journal 61: 1024-1030.

[47] Zhang, R. (1998): Estimating soil hydraulic conductivity and macroscopic capillary length from the disk infiltrometer. - Soil Science Society of America Journal 62: 15131521. 